\title{
The Presence of Carnism on Portuguese Television
}

\author{
Rui Pedro Fonseca \\ Center for Research and Studies in Sociology (CIES-IUL), Lisboa, Portugal \\ Email: fonsecarppd@hotmail.com
}

Received 24 February 2015; accepted 8 August 2015; published 11 August 2015

Copyright (C) 2015 by author and Scientific Research Publishing Inc.

This work is licensed under the Creative Commons Attribution International License (CC BY). http://creativecommons.org/licenses/by/4.0/

(c) (i) Open Access

\begin{abstract}
This paper presents the results of a research about carnism on Portuguese television. It begins by presenting a case study of MasterChef program (TVI) which conveys carnism in both practices and language, and from which some characteristics of their dominant representations are described. Subsequently, the paper presents the indicators of the presence of carnism in the Portuguese television programming between 2013 and 2014, in the TVI, RTP1 and SIC channels. The data reveals that there is hegemony of the carnist ideology in the main channels of the Portuguese television. Also, the samples collected and viewed show no mention of the impacts of carnism in its various dimensions (non-human animals, environment, human health and sustainability).
\end{abstract}

\section{Keywords}

\section{Carnism, Speciesism, Television, Portugal}

\section{Introduction}

Carnism, like other discriminatory cultural hegemonic ideologies, was and is grounded by one of the great ideological structures: the media. The media culture has played a central role affecting all aspects of contemporary social life (Cf. Crane, 1992: 1). Particularly television, whose effects are determining on how it affects the audience and society in general, plays a key role in the dissemination of carnism. Like any other ideology, carnism can also be measured quantitatively and characterized qualitatively.

The first major goal of this paper is to understand the behavioral and linguistic patterns that characterize carnism. To this effect, the first chapter examines a case study with explicit images and the corresponding dialogs of competitors Cristina, Sónia and Margarida during the broadcasting of MasterChef TVI program (Episode 8). Because the language that is used to describe reality also determines one's perceptions, it was necessary to clarify the structure of the dialog through a diachronic analysis on the main language components. In addition, con- 
tributions of reference authors in the areas of animal studies and culture sociology were used to back this analysis. Carol Adams ("The Sexual Politics of Meat: a Feminist Vegetarian Critical Theory", 2010) is essential to understand the concept of "absent reference" used to describe linguistic descriptions and nonhuman animals representations. Melanie Joy ("Why we love dogs, eat pigs and wear cows", 2010) allows us to understand the concept of carnism as a set of discriminatory practices, through eating habits, involving specific animal species. The concept of habitus, by Pierre Bourdieu ("El Sentido Práctico", 2007), is an essential contribution because carnism also implies, by the individual, the embodying of structures, traditions and norms accepted as "correct" and "natural". Because carnism is leveraged by [food] culture, the book of John Fiske ("Introdução ao Estudo da Comunicação", 1990) brings light to concepts like culture, ideology, norms and conventions. John Fiske (Idem, 1990) and Diana Crane ("The Production of Culture of Media and the Urban Arts", 1992) were also useful for their institutional analyses about the media and television.

The second major goal of this article was to measure the presence of carnism in Portuguese television programs (TVI, SIC and RTP1) between 2013 and 2014. To access the programming of the three TV stations, and cover all kinds of television programs (series, newscasts, soap operas, contests, reality shows, talk shows and documentaries), we needed to consult the official programming schedules and analyze 89 programs broadcasted between 2013 and 2014. We used Youtube and the TV station websites to view two examples of each program in order to measure:

a) The presence and types of carnistic representations;

b) If the representations mentioned/deconstructed the impact that livestock industries had on the environment, the exploitation of animals, human health, and natural resource management.

After viewing the TV programs, we found a pattern of 5 categories in which carnism is represented, i.e.: 1) Promotion of animal source food recipes; 2) Promotion of traditional animal source food products, produced locally, by districts; 3) Animal source cooking competitions; 4) Reproduction of inter-personal relationships (friends, family, business meetings, etc.) at dinners, lunches, parties, etc. based on animal source foods; 5) News coverage promoting food events based on animal source foods, or promoting animal source product markets. After determining the categories, we measured the presence, or frequency, of carnistic representations.

\section{Carnism in the MasterChef Program (a Case Study)}

Food is a powerful and complex cluster of cultural practices and beliefs that constantly intersects the categories of nature and culture. The human stomach can digest almost everything, so the distinction between "edible" and "inedible" has no physiological basis, rather a cultural basis. The culinary ceremonies integrated in socialization practices, the language and representations we share classify the nature in different categories: the "edible" and "inedible" animals; the animals with which we do not establish emotional bonds and those with which we do. It is precisely that hierarchical and discriminatory categorization of non-human animals that enforces carnism. The carnist ideology is widely shared, based on a collective mythology, and does not require any justification because it corresponds to a dominant view that is expressed in the discourses and practices (perceived as neutral). However, although it is a time-constant ideology, it can be deconstructed. The case study analyzed in this chapter, one among many hundreds of others, can help understand the behavioral and linguistic characteristics that embody carnism.

In the MasterChef program (TVI), Episode 8 (04.26.2014), two teams compete to please the jury with cooked "goat" and "lamb". The blue team has chosen to prepare both goats, by converting them into food. The dialogue and images between Cristina, Sónia and Margarida (Blue team) embody a familiar sample of what can happen in everyday life, repeatedly, in identical interaction scenarios (see Figure 1). The dialogues and images between competitors begin by showing that both would have to dismember the two goats before cooking. A shock effect arises both during the washing process until the fragmentation process. The shock comes from the fact that the animals are presented as dead, but with their whole body (with head, eyes, teeth): with signs identifying them as (baby) individuals. The alleged resemblance of baby goat corpses with other living animals (like dogs) presented difficulties to both competitors during the fragmentation process. The third competitor, Margarida, showed more emotional disconnection towards the corpses and helped in the fragmentation process.

Like most of the Portuguese population, when Cristina and Sonia cook or eat meat they only perceive food. They focus on its flavor, aroma, and texture, and they don't make a mental connection between the meat and the 


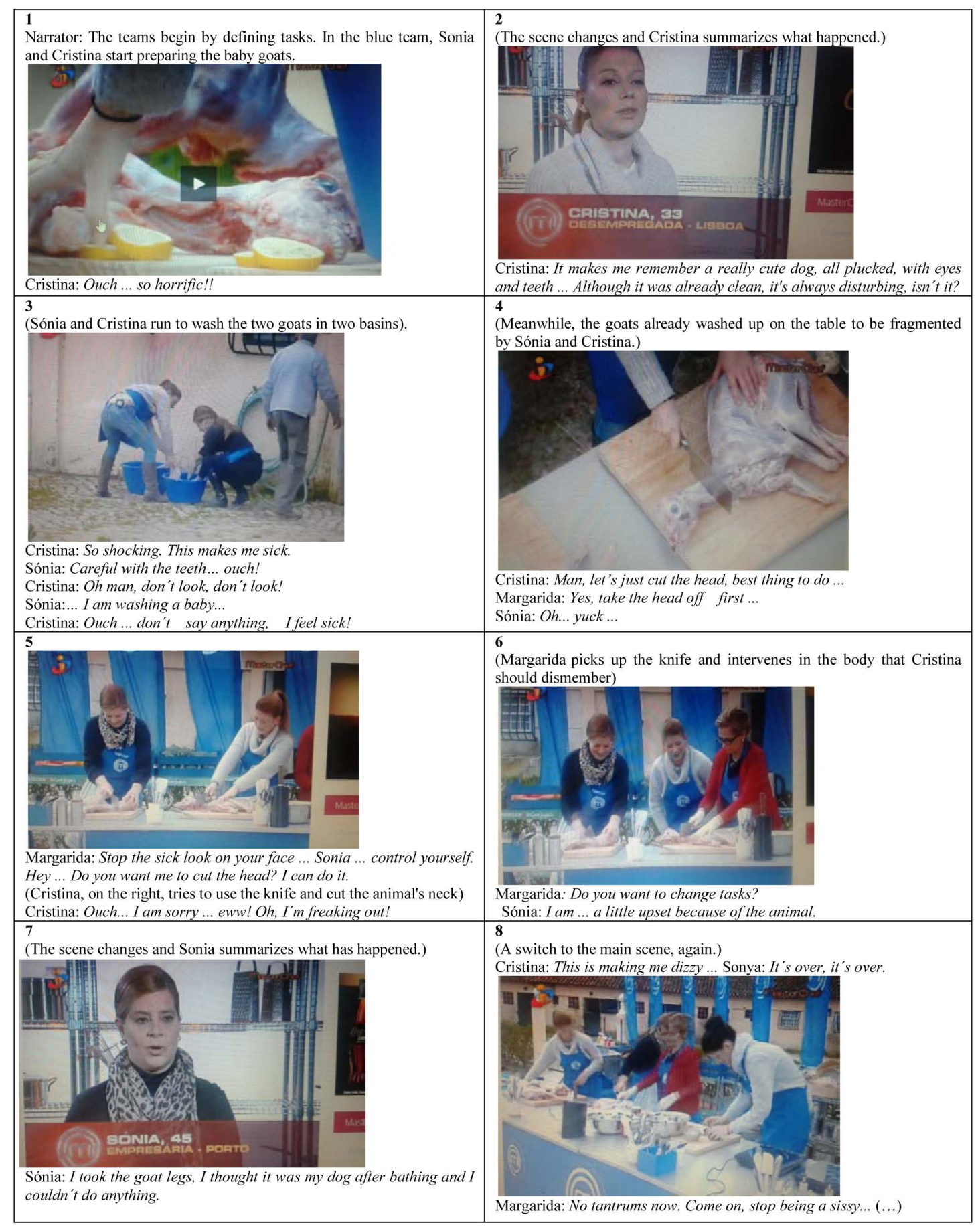

Figure 1. The manifestation of carnism in MasterChef (TVI) [1] show.

animal that was once alive. One of the fundamental steps of the "assembly line" during the program-the fragmentation of the animals for meat-caused in both a shock effect: though dead, the goats were not yet converted into what Adams defined as "absent referents": because they were not yet removed from their individuality - they were whole bodies to become fragmented and to be turned into food. Cristina and Sonia also refused to fragment the corpses by the physical similarities that allegedly they had with dogs. In the internal structure of the competitors, their representations derived from direct or indirect experiences, the dogs do not constitute as food-regardless of whether their cooked meat could be pleasant to the taste. In the representations and expe- 
riences for both, the dog plays and runs to fetch the ball, and/or has moments of affection with its tutor. By contrast, the goat (alive) is missing in the affective everyday experiences of both competitors. However, goat meat is very present in their daily lives; it could be present on the birthday of the oldest member of the family, or part of the last Sunday Easter with the family. This common symptom of reacting differently to different types of meat (and exploited animals) is not because there is a physical difference between them, but because perception towards animals is divergent.

Sónia and Cristina have, since childhood, embodied a belief system, usually unquestioned, which sometimes legitimates, and sometimes sanctions, the exploitation of certain species of non-human animals. As a rooted and hegemonic cultural practice-carnism apparently became naturalized; but it is not neutral. Associated with carnism there are traditions, practices, and routines that, in articulation with popular culture and globalized culture in a given context, embody regulations. The carnist culture is dominant because it is always presented as the culture, as the reference point that contains the norms and the values, the dominant practices as legitimate and others as punishable: so is appropriate to eat cows, but inappropriate to eat dogs; it is appropriate to eat pigs but inappropriate to eat dolphins; it is appropriate to eat cod, but inappropriate to eat whales; it makes sense to drink cow's milk, but it doesn't make any sense to drink mare's milk, etc.

The only relationship that most Portuguese have with cows, pigs, poultry and some fish species is when they are served on the plate, with the fragmented remains of what were once sentient individuals. The perception of animal food is sensitively guided by taste, aroma, texture, and emotionally by representations and beliefs; and we must add the physical and emotional disconnection towards animals whose breeding and slaughtering process is hidden and silent. Vocabulary is objectifying and othering: we speak of fragmented bodies of animals ("steak", "fillet”, "hamburger”, "bacon”, etc.); there are gastronomic designations culturally conceived as food, and for which there is a general consensus, institutionally strengthened (by the media, family, school, state), which is the baseline of a process in which

"Not only do our beliefs ultimately lead to our actions, but our actions also reinforce our beliefs. The more we don't eat dogs and do eat cows, the more we reinforce the belief that dogs are inedible and cows are edible." [2]

[Food] culture provides meaning not only to the reality or external nature, but also to the social system of which it is part, as well the daily activities of those that belong to this system. As a cultural practice, carnism is an active hegemony, in both representations and language, which consolidates and reproduces (as a set of norms) in social practices. A norm is an average example, statistically calculated-it integrates the common practices of a group or society and is, therefore, predictable, expected [3]. The generally accepted conventions are close to the standard; the unexpected, the unconventional, is a deviation from the norm. Similarly, carnism is the expected standard, and is expected to be reproduced in cultural practices. Inversely, veganism is unconventional and therefore a deviation from the norm. Therefore, carnism is neutral; veganism isn't.

Being carnist involves the use of a common habitus ${ }^{1}$, it means being socially constructed, being subjected to a set of rules, conventions, codes, languages, values, and share sets of perceptions that underlie the animal products as legitimate. Although is intensified by capitalism, carnism is a product of history, by past and present experiences and representations that do maintain correspondent practices-also built by consumers.

\section{The Presence of Carnism on Portuguese Television}

The automation of carnism, which depends on human relations of domination towards non-human animals, is carried out by institutions and social groups. It also depends on the loyal and reiterated ritualization of each consumer, and is based on objective mechanisms that constantly reinforce it through collective sanctions and omissions. The enhancement of carnism is a product of home and public spaces, from where people inculcate and reproduce, from generating schemes, the familiar/traditional practices. But carnism also reproduces itself through disseminated practices by the media, particularly by broadcasting programs. In Portugal, television is central for the construction process of social reality, and its representations, regarding carnism, emphasizing certain ideas and values over others; it presents a (culturally based) consensus for non-human animals and, therefore, shapes itself for the audiences, but also reinforces their attitudes and behaviors.

Given the key issue of this paper, which involves assessing the presence of carnism on Portuguese television, we analyzed 89 broadcasting programs in the main Portuguese Television channels (TVI, SIC, RTP1) between

${ }^{1}$ The Concept of habitus mentioned by Bourdieu is appropriate when we talk about carnism because it translates the subjects' incorporation of structures, norms and traditions accepted as "correct" and "natural". 
2013 and $2014^{2}$. We used YouTube and television stations websites to view two examples of each program grid, covering all kinds of television genres: series, newscasts, soap operas, contests, reality shows, talk shows and documentaries (see Table 1 and Table 2).

Table 1. The dominant categories and evidence of carnist ideology in programs broadcasted by Portuguese television (Channels: TVI, SIC, RTP) between 2013 and 2014.

\begin{tabular}{|c|c|c|c|c|c|}
\hline Well evident & Quite evident & Not evident & $\begin{array}{c}\text { Telltale/deconstructive } \\
\text { of livestock impacts on animals }\end{array}$ & $\begin{array}{l}\text { No } \\
\text { data }\end{array}$ & Total \\
\hline $\begin{array}{l}\text { *Promotion of animal based } \\
\text { recipes. } \\
\text { *Promotion of } \\
\text { traditional/local } \\
\text { produce from various districts } \\
\text { in Portugal (e.g., Cheeses, } \\
\text { sausages, pig meat, lamb, etc.). } \\
\text { *Cooking competition } \\
\text { practices involving animal } \\
\text { products. }\end{array}$ & $\begin{array}{l}{ }^{*} \text { Reproduction of inter-personal relations } \\
\text { (friends, family, business meetings, etc.), } \\
\text { (e.g., dinners, lunches, parties) } \\
\text { with animal products } \\
\text { "Block news involving the } \\
\text { animal product market } \\
\text { (e.g., prices of beef or the } \\
\text { crisis in the dairy sector) } \\
\text { or even promote culinary } \\
\text { events with animal products. }\end{array}$ & $\begin{array}{c}{ }^{*} \text { No evidence } \\
\text { of } \\
\text { representations } \\
\text { and/or lan- } \\
\text { guage } \\
\text { linked to } \\
\text { carnist } \\
\text { ideology. }\end{array}$ & $\begin{array}{l}\text { In the collected samples } \\
\text { there are no mentions } \\
(0 \%) \text { that report on } \\
\text { the livestock industry } \\
\text { impacts on exploited } \\
\text { animals, on human } \\
\text { health, environment, } \\
\text { or on the management } \\
\text { of natural resources } \\
\text { (e.g., food, water, energy). }\end{array}$ & & \\
\hline $\begin{array}{c}13 \\
(15 \%)\end{array}$ & $\begin{array}{c}39 \\
(44 \%)\end{array}$ & $\begin{array}{c}29 \\
(33 \%)\end{array}$ & $\begin{array}{c}0 \\
(0 \%)\end{array}$ & $\begin{array}{c}8 \\
(9 \%)\end{array}$ & $\begin{array}{c}89 \\
(100 \%)\end{array}$ \\
\hline
\end{tabular}

Table 2. Evidence of the carnist ideology in Portuguese television programs (Channels: TVI, SIC, RTP) in 2013 and 2014.

\begin{tabular}{|c|c|c|}
\hline Channels & Television programs & Presence of carnism \\
\hline \multirow{33}{*}{ TVI } & Doce Tentação & Quite evident \\
\hline & Louco Amor & “ $\quad$ \\
\hline & Mundo ao Contrário & ” \\
\hline & Doida por Ti & ” \\
\hline & Destinos Cruzados & ” \\
\hline & Belmonte & $”$ \\
\hline & I Love It & ” \\
\hline & Lie to $\mathrm{Me}$ & Not evident \\
\hline & Você na TV! & Quite evident \\
\hline & A Tarde É Sua & Well evident \\
\hline & Não há Bela sem João & Quite evident \\
\hline & Somos Portugal & Well evident \\
\hline & Secret Story-Casa dos Segredos: Desafio final & Quite evident \\
\hline & A Tua Cara não me é Estranha & Not evident \\
\hline & Big Brother VIP & Quite evident \\
\hline & Dança com as Estrelas & Not evident \\
\hline & Secret Story-Casa dos Segredos & Quite evident \\
\hline & Secret Story-Casa dos Segredos: Desafio Final 2 & " \\
\hline & A Tua Cara não me é Estranha Kids & Not evident \\
\hline & MasterChef Portugal & Well evident \\
\hline & Rising Star-A Próxima Estrela & Not evident \\
\hline & Dança com as Estrelas & “ $\quad$ ” \\
\hline & Secret Story-Casa dos Segredos & Quite evident \\
\hline & Diário da Manhã & Not evident \\
\hline & Meteorologia & “ $\quad$ ” \\
\hline & Jornal da Uma & Quite evident \\
\hline & TVI Negócios & Not evident \\
\hline & Repórter TVI & Not evident \\
\hline & Jornal das 8 & Quite evident \\
\hline & Animações & No data \\
\hline & Kid Kanal & “ $\quad ”$ \\
\hline & Festa do Emigrante & Well evident \\
\hline & Festa de Verão TVI & Not evident \\
\hline
\end{tabular}

${ }^{2}$ RTP1, SIC and TVI are the main general television channels in Portugal, with more audience, and with free access. Because they have more audience compared to pay channels, are representative enough to access the carnist ideology. 


\section{Continued}

SIC

RTP1
Sol de Inverno

Mar Salgado telenovela

Camilo, o Presidente

Cenas do Casamento

Senhora do Destino

Amor à Vida

A Guerreira

Rex, O Cão Polícia

NCIS: Los Angeles

Querida Júlia

Queridas Manhãs

Sextas Mágicas

O Formigueiro

Portugal em Festa

Os Vídeos Mais Loucos do Guiness World Records

$$
\text { Sabadabadão }
$$

Os Segredos da Magia

$$
\text { Vale Tudo }
$$

Splash! Celebridades

$$
\text { Factor X }
$$

O Poder do Amor

Edição da Manhã

Jornal de Síntese

$$
\text { Dance }
$$

Os Protegidos

Sam Fox: Aventuras Extremas

$$
\text { Etnias }
$$

Episódio Especial

Último Jornal

Fama Show

Gosto Disto

Sábado à Luta

Bom Dia Portugal

Jornal da Tarde

Portugal em Direto

Telejornal

Praça da Alegria

Portugal no Coração

5 para a Meia-Noite

Aqui Portugal

Sabe ou Não Sabe

Quem Quer Ser Milionário

Sexta às 9

Biosfera

Voz do Cidadão

BBC Terra

Chefs Academy Kids

Janela Indiscreta

Breviário Biltre

Vivo em Portugal

Só Visto!

Hora Da Sorte

Os Filhos Do Rock

Habitat

Nós

Prós e Contras
Quite evident

“

“ ”

“

“ ”

“ ”

“ ”

“ ”

“ ”

“ ”

No data

Well evident

No data

Not evident

“

Quite evident

Not evident

“

Quite evident

No data

Well evident

Quite evident

Quite evident

Not evident

Quite evident

Not evident

Quite evident

“

Well evident

Quite evident

Well evident

،

Not evident

،

“

“

"

“ ”

Well evident Not evident Quite evident Well evident Quite evident Not evident Quite evident “

Well evident Not evident 
Data from this study reveals that carnism is very much in evidence in $15 \%$ of television programming in Portugal, as it reiterates and encourages the consumption, sale or offers animal based recipes. In Portuguese entertainment programs and talk shows such as "Portugal no Coração", "Vivo em Portugal”, "Praça da Alegria”, "A Tarde é Sua”, "Portugal em Festa”, among others, food recipes are promoted live, as well as traditional, local produce from various districts in Portugal (e.g., cheeses, sausages, piglet, lamb, etc.). The MasterChef and MasterChef Kids competitions feature cooking practices where most of the products are animal based. Although the recipes used by competitors match both international and Portuguese contexts, they also follow the cultural requirements of carnism (exploration and hierarchization of certain species of animals for food consumption).

Carnism was evident in $44 \%$ of the Portuguese television programming. Soap operas like "Doce Tentação", “Belmonte”, “Mundo ao Contrário”, “Destinos Cruzados”, "Mar Salgado”, "Sol de Inverno”, etc.; reality shows such as Secret Story, Big Brother, foreign or Portuguese series, such as "A Guerreira”, "Rex, o Cão Polícia”, “NCIS: Los Angeles”, “Os Protegidos”, “Breviário Biltre”, reproduced and conveyed interpersonal relationships with friends, family, business meetings, etc., which revolve around carnist practices (e.g., dinners, lunches, parties). News blocks such as “Jornal da Uma”, “Telejornal”, “Último Jornal”, “Jornal da Tarde”, among others, present news that involve the animal product market (e.g., beef prices or the crisis affecting the dairy sector) or the promotion of carnistic culinary events.

On the other hand, 33\% of television programming in Portugal consisting of song contests (e.g., "Rising Star A Próxima Estrela”); dance competitions (e.g., "Dança com as Estrelas”); other competitions (e.g., "A Tua Cara não me é Estranha”); weather (e.g., “TVI Meteorologia”), or news reports (e.g., "Repórter TVI”) show no evidence of food practices and language linked to carnist ideology.

The examples we collected and viewed made no reference $(0 \%)$ to the impact of the livestock industry on exploited animals, or on other areas: human health; environment; management of natural resources (e.g., food, water, energy).

We were unable to obtain samples of entire programs in 9\% of the Portuguese television programming ("Sextas Mágicas”, “O Formigueiro”, “Sam Fox: Aventuras Extremas”, “Os Vídeos Mais Loucos do Guinness”, “World Records, "Sabadabadão”, Animações “Kid Kanal”).

\section{Conclusions}

The case study (dialogue between Cristina and Sonia in MasterChef) proves to be representative of a vast universe whose action is consistent with the dominant ideology: carnism. This ideology advocates the emotional disconnection between the "meat" and animals as sentient individuals, as well as the hierarchization and discrimination of species of animals (e.g., caring for dogs and cats, but eating pigs and cows). Carnism also reveals itself through representations and language: cows, pigs, birds, other mammals, and some species of fish are othered, set within and objectified both in discourses and images, converted physically and linguistically into “filetes”, “bacon”, “bitoques”, “fêveras”, “bifes”, "Bacalhau à Gomes de Sá”, etc.

According to the data collected, the carnist ideology is present in 59\% of the Portuguese television programs (15\% well in evidence and 44\% quite evident). On TVI, SIC and RTP1 (advertising not included) carnism appears as: promotion of animal based food recipes; promotion of traditional/local animal based food; promotion of cooking competitions with various animal based food recipes; reproduction of personal interrelationships around animal based food; news blocks that commodify livestock animals.

Carnism is institutionalized by the Portuguese television, which promotes and encourages the acceptance of discriminatory attitudes and behaviors towards specific animal species. One leading cause to the hegemony of carnism has to do with the non-participation of non-human animals in the discussions about language, consequently in their own social construction [4]. In other words, the language and the representations commonly used allow the cover-up of coercive handling; physical, emotional and psychological oppression towards nonhuman animals, as well the cover-up of the resulting impacts caused by the livestock industry. A second factor consists in formulating a consensus around carnism through the internalization and sharing of eating habits promoted by television workers who, due to their condition, present behavioral style patterns, and similar patterns of language, nonverbal communication, tastes, values, ways of perception and reasoning [5], forming the external structures that are consistently perpetuated [6]. The third factor resides in the institutional status of television stations. Since they depend on funding (e.g., from advertising), the ideas, the meanings and above all the underlying economic system of television seeks to make the carnist culture seem natural and to disguise it. By 
presenting such high indices of cultural carnism, the Portuguese TV broadcasting not only mirrors the consumer's own image, but also reinforces the ideology, and assimilates the consumer into the carnist culture and market-sustaining their vitality.

Although there is no carnist-related language or representation in 33\% of television programs in Portugal, no reference is also made to the impact of the livestock industry on: exploited animals, human health, environment, and sustainability. Because it strengthens the status quo, because it is the result of representations, of ignorance derived from omissions, we can conclude that Portuguese television is not neutral, but rather active in the foundation of the hegemonic carnism.

\section{References}

[1] MasterChef TVI (Episode 8-26-04-2014): http://www.tvi.iol.pt/masterchef/videos/masterchef-cabrito-e-borrego-vao-ser-confeccionados-pelas-equipas/14130399

[2] Joy, M. (2010) Why We Love Dogs, Eat Pigs and Wear Cows. Conari Press, San Francisco.

[3] Fiske, J. (1990) Introdução ao Estudo da Comunicação. Edições Asa, Porto.

[4] Stibbe, A. (2001) Language Power and the Social Construction of Animals. Society \& Animals. Koninklijke Brill NV, Leiden.

[5] Swartz, D. (1997) Culture \& Power (The Sociology of Pierre Bourdieu). University of Chicago Press, Chicago

[6] Bourdieu, P. (2007) El Sentido Prático. Ediciones Sieglo, Salamanca. 